\title{
The Application of Podcasting as a Motivational Strategy to Iranian EFL Learners of English: A View toward Listening Comprehension
}

\author{
Saeed Shiri \\ Dept. of English Language and Literature, Faculty of Humanities, Isfahan University, Isfahan, Iran \\ E-mail: shirisaeed@yahoo.com
}

Doi:10.7575/aiac.alls.v.6n.3p.155

URL: http://dx.doi.org/10.7575/aiac.alls.v.6n.3p.155
Received: 09/02/2014

Accepted: 15/04/2015

\begin{abstract}
This study was conducted in order to inspect the impact of podcasts as learning and teaching tools on Iranian EFL learners' motivation for listening as well as on their listening comprehension ability. It also investigated the learners' perception towards podcasts. 34 intermediate learners who were homogeneous in terms of listening ability were chosen and then assigned into two groups. While the experimental group were given the treatment i.e. podcasts, the control group received the traditional practice. Data analysis results showed that the learners in the podcasting group surpassed the participants in the control group in their listening comprehension tests and in ELCMS scale as used to measure changes in the motivation of learners for listening. Students' views about the program were also elicited via podcast contribution questionnaire and individual interviews. The analysis of qualitative data showed that students perceived improvement in their listening achievement.
\end{abstract}

Keywords: CALL, Listening skill, Motivation, Motivational strategies, Podcast

\section{Introduction}

Motivation is considered to be a key concept both in psychology and language education. Those concerned with education, including teachers, students, and parents, mostly use the term to account for students' success or failure in educational settings. Indeed, language learners need motivation to provide major drive to begin language learning and later on the motivating force to continue the long and lengthy process of language learning (Williams \& Burden, 1997).

Traditional views of motivation have mostly tried to define the concept of motivation rather than how it can be used in educational settings to inspire hope to unmotivated learners. Recently, however, more and more researchers have embarked on the investigation of the educational implications of motivational strategies (e.g., Alison \& Halliwell, 2002; Dornyei, 2001, 2006). Therefore, motivational research has reached maturation in terms of theoretical advances that they have begun to contribute to developments in practice and methodologies.

As Dornyei (2007) suggests there should be, in research, an emphasis on evaluating the teachability of motivational strategies in general and on discovering innovative ways to teach the strategies in particular. In this vein, one of the most powerful motivational strategies, as Madrid (2002) investigated, among 19 different motivational strategies, perceived by the students and teachers alike, is the use of new technologies including audiovisual resources. In this regard podcasting as a newly developed technological phenomenon in the realm of computer-assistant language learning and mobile-assistant language learning is one of the promising innovations that as an educational tool can contribute to higher level of motivation and language achievement in English learners.

Accordingly, as Cebeci \& Tekdal (2006) state, podcasting offers a great opportunity for learning through listening. For some learners, listening might be more attractive and less tiring than reading. Hasan \& Hoon (2012) have found in their study that podcasts motivates learners towards learning English and improves their language skills, especially listening. To those students who do not like reading listening might prove to be motivating. This unique feature of listening is provided appropriately in podcasting that is teaching through talk rather than text. According to Rost (2006), ELT podcasts are particularly appropriate for the practice of extensive listening, for the purpose of motivating students to listen, as well as giving them the opportunities to listen to native speakers of English.

This study, thus, tries to look into the possible effects of podcasting as a motivational strategy on the Iranian EFL learners' motivation to listen to audio material and whether there happens any improvement in their listening skill. The study will also examine Iranian learners of English readiness to accept and welcome the new technology in their classes.

\section{Literature Review}

We need some clear theoretical background to support any investigation. Thus, the second part of the current paper is to review the most related part of literature. The review takes three variables of the study; students' motivation to listen 
and the incorporation of podcasts into EFL classrooms, as well as listening comprehension improvements into consideration in two separated parts.

\subsection{Motivation}

In the realm of language learning, motivation has long been identified as a key aspect that determines L2 achievement and attainment. Motivation serves as the major element to generate learning and consequently, in the long process of learning, functions as a constant powerful force that helps to continue generally demanding journey of learning a foreign language. If lacking sufficient motivation, it would be really demanding even for the very quick learners "to master the higher levels of L2 proficiency" (Dornyei \& Csize'r, 1998).

Due to this importance, L2 motivation has been the subject of a considerable amount of research in recent decades. Before the 1990s, the research on L2 motivation had been dominantly influenced by the influential work of two Canadian psychologists, Robert Gardner and Wallace Lambert (1959, 1972), who conceptualized motivation from a perspective which was primarily social and psychological. In their view, L2 was "a mediator between different ethnolinguistic communities" and hence the motivation to learn the language of the target L2 community was believed to be an important factor in "promoting or hindering intercultural communication"(Dornyei \& Csize'r, 1998).

However, Gardner's approach to motivation has failed to explicitly address the classroom implications of motivation theory and also fell short to aim at providing direct help to language teachers in advancing the teaching endeavor (Cheng and Dornyei, 2007). Turning the 1990s, many L2 researchers began to conceptualize motivation in a new way and marked shift was mirrored in a number of studies calling for a more classroom-oriented approach that was more in line with mainstream educational psychological research (e.g. Dornyei, 1990, 1994; Oxford \& Shearin, 1994; Tremblay \& Gardner, 1995; Williams \& Burden, 1997). The new approach was successful in promoting and expanding the L2 motivation paradigm by (1)" promoting cognitive aspects of motivation, especially those related to the learner's 'self' (e.g. need for achievement, self-confidence/efficacy, self-determination); (2) integrating various influential theories that were already prevalent in mainstream psychology (e.g. goal theories and attribution theory); and (3) focusing on situational factors relevant to classroom application (e.g. characteristics of the language course and language teacher)"(Cheng \& Dornyei, 2007, p. 154).

With motivation being one of the key factors causing second language learning success, motivational strategies should be investigated as a significant aspect of motivation. Nevertheless, there has been a dearth of studies in the literature on developing techniques to increase motivation. Surprisingly, there has appeared a growing number of L2 scholars designing and studying motivational techniques for L2 classroom use in the past decade (e.g. Alison \& Halliwell, 2002; Brown, 2001; Madrid, 2002), even devoting a whole book to this topic: Motivational Strategies in the Language Classroom (Dornyei, 2001b), listing more than 100 effective motivational techniques supported with a inclusive theoretical framework.

In this regard, podcasts, if applied properly, might provide the language learners with the motivation which they need to maintain the lengthy and sometimes tiresome process of learning a new language by offering them some control over the input they get exposed to and taking advantage of a popular (especially with young people) technology. Ehrman, Leaver and Oxford (2003) mention two principal forms of motivation: intrinsic, that happens whenever tasks are "interesting and challenging [and] the reward is the enjoyment of the activity itself" (op. cit.: 320), and extrinsic, when given grades or encouragements are the incentive for learning.

\subsection{Podcasting}

Podcasting phenomenon, an innovative technology for broadcasting audio files and programs on the Internet has been introduced in 2005 and since then there have appeared rapid advances (Selingo, 2006). Podcasting which was originally a tool for conveying information, news, and entertainment, soon, was detected by educators who properly noticed the potential it can have for teaching and learning (Adams, 2006).

In the U.S., the Office of Information Technology of Minnesota University argued that podcasting entails a shift from electronic learning to mobile learning (2006). The Office (2006) identified a number of possible applications of podcasts in education, such as news, student-spoken podcasts, and guest lecturers, to name a few, which would help students develop listening as well as, when attempting to produce podcasts, speaking skills. In fact, many researchers have called attention to the benefits that podcasting offers language learning, particularly with regard to widening L2 learners' listening and speaking skills (e.g. Pun, 2006; Stanley, 2006).

Meanwhile O'Bryan and Hegelheimer (2007) warn educators on not to use podcasting not, as the sole tool of instruction and make it the focus of attention in L2 courses. Instead, according to them, we should include podcasts into the syllabus, and make them appear invisible. What makes podcasts advantageous over other invisible tools is how they are mobile and can be used on the go (O’Bryan and Hegelheimer, 2007).

English learning podcasts can be utilized for both extensive and intensive listening activities. However, ELT podcasts are essentially appropriate for listening activities which are extensive, which can motivate students to listen to English, and provides them with optimal exposure to native speakers' speech (Rost, 2006). Similarly, Ashraf, Noroozi and Salami (2011) have reported the "positive attitudes" of their participants who were instructed to use podcast files as a listening material, and came to the conclusion that they can be employed to develop the listening skill of language learners. Stanley (2006) found out that podcasting offers students a "range of possibilities" for more and more listening practice not only inside but also outside of the classroom and at the convenience of their time: "Supplementing the 
(often) scripted and stilted textbook listening with the real life authentic conversations you can find on many podcasts is an attractive option for language teachers. Chosen carefully, extracts can bring a range of different voices and varieties of English into the classroom". Alternatively, there are many authentic podcasts which more advanced learners can be encouraged to listen to. By employing this, the gap between the formal and didactic use of English which takes over almost all language learning settings and the casual English spoken in real-life communication situation can be filled (Stanley, 2006). Similarly, the use of authentic texts offered by ELT podcasts has been reported to enhance intrinsic motivation of learners which is also partly due to "motivational appeal" of technology-based learning tools (O'Bryan and Hegelheimer, 2007).

Thus, this study as its primary objective will seek to find out the educational benefits of podcast use in the language classrooms. The aim of the study is also to investigate whether this new technology is welcomed by Iranian learners of English and the extent to which the students participating in the study will be motivated to listen to learn through podcasts as well as to see how, as the result of this motivation, they improve in their listening comprehension.

Considering the aforesaid issues, the current study attempts to offer reasonable answers to the research questions which follow:

1) Does the application of podcasts as a motivational teaching strategy significantly affect the students' classroom motivation?

2) Do the motivated students significantly outperform the less motivated students on the test of listening comprehension?

3) What are the students' attitudes towards podcasting as a new technology in promoting their motivation in learning?

Regarding the research questions, the following hypotheses can be formulated:

1) The application of podcasts as a motivational teaching strategy does not significantly affect the students' classroom motivation.

2) Motivated students do not significantly outperform the less motivated students on the test of listening comprehension.

3) Students in the study do not have any special kind of attitude towards podcasting as a new technology in promoting their motivation in learning.

\section{The study}

As mentioned before, the primary purpose of the study was to examine the effect of listening to podcasts on Iranian EFL learners' listening ability. Moreover, the study aimed at investigating whether the application of podcasts as a motivational teaching strategy significantly affect the students' motivation. The participants' perceptions about the impact of podcasts on listening motivation as well as their perceptions about podcasts were elicited via a questionnaire and individual semi-structured interviews. The present study followed a mixed methods approach, in that it combined both quantitative and qualitative methods of data collection and data analysis. The quantitative section includes the part of the study which deals with the effect of podcasts on students' listening ability as well as on students' listening motivation level. The qualitative section includes the part which deals with students' perceptions about the effect of using podcasts as a learning tool and their perceptions about the podcast program.

\subsection{Participants}

55 intermediate EFL learners at an English institute which was a branch of one of the biggest organized institutes nationwide were the participants in the study. They were composed of high school and college students as well as some graduate students. They had passed all the prerequisite previous courses at the institute, their current term being $10^{\text {th }}$ out of $18^{\text {th }}$. While a few of the learners had been studying at the institute from the beginning levels, that is for ten terms, others had been studying for shorter periods of time as learners entering the institute needed to take placement test. They were given a listening test consisting of 20 listening questions and 34 of them who were homogeneous in terms of listening ability were chosen as the participants in the main phase of the study. Class A with 18 participants and class B with 16 participants were the experimental and control groups, respectively. However, one participant in the experimental group did not continue, thus, only 17 participants were included in the post-test. A bio-data questionnaire given at the beginning of the semester showed that the participants in the podcast group were aged between 14 and 28 at the time of the study and none of them had experienced podcasting in their classes i.e. they were all taught listening in the classroom constraint in their previous classes, that is all their opportunities to practice listening was confined to teacher's talk and listening activities they had to accomplish in the classroom.

The non-parametric test of Kolmogorov-Smirnov (K-S test) test was used to see whether the participants' listening scores in the pretest were normally distributed. As shown in Table 3.1, the p value of .56 is greater than the p-value of .05 . This means that the participants' listening scores in the pretest were normally distributed, that is the normality can be assumed in the data; hence resorting to parametric tests in order to perform statistical analyses. Thus, to verify the homogeneity of the control and experimental groups in terms of listening ability in the pre-administration of the listening test, using SPSS 13, an independent samples t-test was conducted. 


\section{One-Sample Kolmogorov-Smirnov Test}

\begin{tabular}{|c|c|c|}
\hline & & prescore \\
\hline $\bar{N}$ & & 55 \\
\hline Normal Parameters $\quad a, b$ & Mean & 12.2727 \\
\hline & Std. Deviation & 2.96557 \\
\hline Most Extreme & Absolute & .106 \\
\hline Differences & Positive & .083 \\
\hline & Negative & -.106 \\
\hline Kolmogorov-Smirnov Z & & .786 \\
\hline Asymp. Sig. (2-tailed) & & .567 \\
\hline
\end{tabular}

a. Test distribution is Normal.

b. Calculated from data.

As it is shown in Table 3.2 the mean scores of the control and experimental groups are 12.72 and 12.50 .

Table 3.2. The Mean Scores of Groups in the Pretest

Group Statistics

\begin{tabular}{|r|r|c|r|r|}
\hline & & & & \multicolumn{2}{|c|}{$\begin{array}{c}\text { Std. Error } \\
\text { group2 }\end{array}$} & $\mathrm{N}$ & Mean & Std. Deviation & Mean \\
\hline prescoremair 1.00 & 18 & 12.7222 & 1.52646 & .35979 \\
2.00 & 16 & 12.5000 & 1.63299 & .40825 \\
\hline
\end{tabular}

To see whether there is a statistically significant difference in the participants' performance, Table 3.3 ought to be examined.

Table 3.3. T-value for the Listening Performance of Experimental and Control Groups in the Pretest

\begin{tabular}{|c|c|c|c|c|c|c|c|c|c|}
\hline \multicolumn{10}{|c|}{ Independent Samples Test } \\
\hline & \multicolumn{2}{|c|}{\begin{tabular}{|l|} 
Levene's Test for \\
Equality of Variances \\
\end{tabular}} & \multicolumn{7}{|c|}{ t-test for Equality of Means } \\
\hline & \multirow[b]{2}{*}{$\mathrm{F}$} & \multirow[b]{2}{*}{ Sig. } & \multirow[b]{2}{*}{$t$} & \multirow[b]{2}{*}{ df } & \multirow{2}{*}{ Sig. (2-tailed) } & \multirow{2}{*}{$\begin{array}{c}\text { Mean } \\
\text { Difference }\end{array}$} & \multirow{2}{*}{$\begin{array}{l}\text { Std. Error } \\
\text { Difference }\end{array}$} & \multicolumn{2}{|c|}{$\begin{array}{l}95 \% \text { Confidence } \\
\text { Interval of the } \\
\text { Difference }\end{array}$} \\
\hline & & & & & & & & Lower & Upper \\
\hline $\begin{array}{c}\text { prescoremair Equal variance } \\
\text { assumed }\end{array}$ & .262 & .612 & .410 & 32 & .685 & .22222 & .54194 & -.88168 & 1.32613 \\
\hline $\begin{array}{l}\text { Equal variance } \\
\text { not assumed }\end{array}$ & & & .408 & 30.901 & .686 & .22222 & .54416 & -.88775 & 1.33220 \\
\hline
\end{tabular}

As seen in Table above (3.3), the $\mathrm{p}$ is .68 which is greater than .05 . This reveals that there is no significant difference between the means. In other words, the groups were homogeneous in terms of listening ability at the beginning of the study.

\subsection{Instrumentation}

Multiple data collection methods were used to obtain comprehensive and useful data and also to increase the validity of the findings.

\subsubsection{Listening Material (Podcasts) as Treatment}

Several units of podcast-based material adopted from a famous ESL podcast project on the web, www.china232.com, which had been normalized and accompanied by learning tasks were introduced to learners in experimental group during the treatment period. The tasks were devised, in part, to magnify the outcome of learning. The content of the listening podcasts was somehow similar to the content of the institute's text book, as they contained reading passages as well as dialogs accompanied with a lot of idioms and spoken expressions in each lesson followed by explaining about each phrase in audio format. These units had been piloted prior to the main study to see whether the tasks were appropriate and the students could effectively do the tasks. Piloting was done with some EFL learners at the same institute, Isfahan Branch. They perceived tasks, via a researcher-made questionnaire and informal interviews, reasonable and appropriate. This was done prior to main study in the spring term, 2013. Piloting proved that the 
intermediate EFL learners studying English at the institute were able to do the given tasks after carefully listening, sometimes several times, to the material.

\subsubsection{English Listening Comprehension Motivation Scale}

A researcher-made version of the ELCMS (the English Listening Comprehension Motivation Scale) was applied to determine students' motivation level for practicing English listening comprehension. The ELCMS items were adopted from Chang's Intrinsic Motivation Orientation Scale (2001). The scale was made up of 17 statements, and the participants were required to score the 17 statements on a five-point Likert Scale, ranging from strongly agree to strongly disagree, each statement scored out of 5. ELCMS was administrated at the beginning and end of the study to the members of experimental group to investigate the changes in the amount of motivation due to supplementary use of podcasts in EFL classes.

\subsubsection{Podcasting Contribution Questionnaire}

A very brief questionnaire was conducted at the end of the study to investigate the perceptions of podcast group (experimental) on the use of podcasts as new listening materials.

\subsubsection{Interview}

In order to elicit students' opinions and perceptions on using podcasts project further yet, the researcher conducted individual semi-structured interviews. Participants were free to answer the teacher-researcher's questions in English or in their own L1. For this purpose, eight students were selected based on their scores.

\subsubsection{Pre- and Post-tests}

A listening task was employed as pre-test and post-test to see whether the participants' listening comprehension improves as the result of listening to podcasts. It consisted of 20 listening questions (ten short conversations and two very brief stories with each passage having five questions).

\subsection{Research design}

There was an experimental and a control group in the quasi-experimental design of the study. A pretest and posttest was given to each group, but due to some practical limitations there was no random selection and assignments of the participants (see Mackey \& Gass, 2005). A listening test was given to each group as the pretest and posttest. The pretest functioned as a two-fold test; first, to select a homogenized group of participants by excluding outliers from the study, and second, to serve as a pretest to be compared with the posttest. While the implementation of podcast listening in the classroom was the independent variable, the listening ability and motivation level of learners in the control group were the dependent variables. The statistical procedures of independent-samples T-test was used to determine if there was any significant difference between the listening ability of the two groups before and after the treatment. The study followed a mixed methods approach in that, to get a better picture of the events, it mixed both quantitative and qualitative methods for both data collection and the analysis of the data collected. Then, inductive thematic analysis was used to analyze the qualitative data, and consequently, the process was followed with the discussion of the themes emerged from the data. Table 3.4. shows the overall design of the study.

Table 3.4. Overall Design of the Study

\begin{tabular}{|c|c|c|c|}
\hline Data & $\begin{array}{c}\text { Number of } \\
\text { Participants } \\
\text { (NP) }\end{array}$ & $\begin{array}{c}\text { NP of } \\
\text { experimental } \\
\text { group }\end{array}$ & $\begin{array}{c}\text { NP of control } \\
\text { group }\end{array}$ \\
\hline Pretest & 55 & 29 & 26 \\
\hline Questionnaire & 18 & 18 & - \\
\hline Treatment & 18 & 18 & - \\
\hline Posttest & 33 & 17 & 16 \\
\hline Questionnaire & 17 & 17 & - \\
\hline Interview & 8 & 8 & \\
\hline
\end{tabular}

\subsection{Procedures}

To conduct the study, two intermediate classes (Intermediate 1, i.e. term 10 out of 18 terms in total) in a large institute were selected. These two classes were instructed on listening to podcasts and teaching listening based on the traditional way which the institute conventionally has been following through several years. One of the classes was considered as the control group and the other class as the experimental. The setting of the study was the summer term (2013) and the location was an institute in Gonbad-Kavoos, Iran. The classes met twice a week for 105 minutes. First of all, to ensure 
their homogeneity in the terms of listening comprehension ability, a listening task consisting of 20 questions was given to the students of both groups. Then based on the students' scores, the researcher decided which students could be qualified as the final participants of the study, using a set of statistical procedures discussed in section 3.2. After selecting the participants $(\mathrm{N}=34)$ a motivational questionnaire was administered to the participants in the experimental group in the first session.

Then during ten successive sessions some units of podcast-based materials were introduced to the experimental group as the treatment. Most of the previous studies had utilized podcasts as the supplementary learning tools as the learners listened to podcasts at home besides attending classes (e.g. Stanley, 2006; Leach, 2006). So did this study. However, the researcher employed the podcasts in the classroom too, mostly due to making sure that participants in the study group would listen to materials at least once. It took about 15 minutes each session to listen to each one of the podcasts which were 9 minutes in average as well as to have some comprehension questions. Then the participants in the experimental group were asked and encouraged to listen to the same podcast at home as homework. Meanwhile, the control group was taught in the institute's conventional way of teaching listening and vocabulary, which was mostly considered to be a modified version of Audiolingualism with a lot of focus on grammar and using different kinds of drills to teach grammar and dialogs with little attention to listening. As the next step, the students' listening comprehension was measured using the post-test listening task.

Finally, the same motivational questionnaire which was used at the beginning of the study for the experimental group was readministered to them. In this way, two sets of the scores on the motivational questionnaire were collected to compare the students' level of motivation and assess the probable changes of the participants' motivation during the treatment.

\subsection{Results}

This section consists of three parts. The first part deals with testing the hypotheses of the study. That is, in this part the quantitative data which are related to the impact of podcasts on the learners' motivation for listening as well as on their listening comprehension ability are analyzed. In the second part, students' perceptions about podcasting project are discussed in the light of qualitative data.

\subsubsection{Testing the Hypotheses}

The statistical procedures of the independent samples t-test was used to investigate the effect of listening to podcasts on Iranian EFL students' motivation level and also on their listening comprehension ability. The results of testing the hypotheses are:

\subsubsection{Testing the First Null Hypothesis}

The first null hypothesis of the study posed that the application of podcasts as a motivational teaching strategy does not significantly affect the students' motivation for listening. In order to test the hypothesis, the non-parametric test of Wilcoxon Signed Rank test was run using SPSS 13 to see whether the experimental group participants achieved higher scores in the post-administration of the ELCMS. Table 4.1 shows the results of the Wilcoxon Signed Rank test.

Table 4.1. The Mean Ranks of Experimental Group in the Pre- and Post-administration of ELCMS

\begin{tabular}{|c|c|c|c|c|}
\hline \multicolumn{5}{|c|}{ Ranks } \\
\hline & & $\mathrm{N}$ & Mean Rank & Sum of Ranks \\
\hline qresult2 - qresult1 & Negative Ranks & $0^{\mathrm{a}}$ & .00 & .00 \\
\hline & Positive Ranks & $17^{\mathrm{b}}$ & 9.00 & 153.00 \\
\hline & Ties & $0^{c}$ & & \\
\hline & Total & 17 & & \\
\hline
\end{tabular}

In order to find out whether there is a statistically significant difference in the participants' performance, Table 4.2 should be examined.

Table 4.2. T-value for the Mean Ranks of Experimental Group in the Pre- and Post- administration of ELCMS

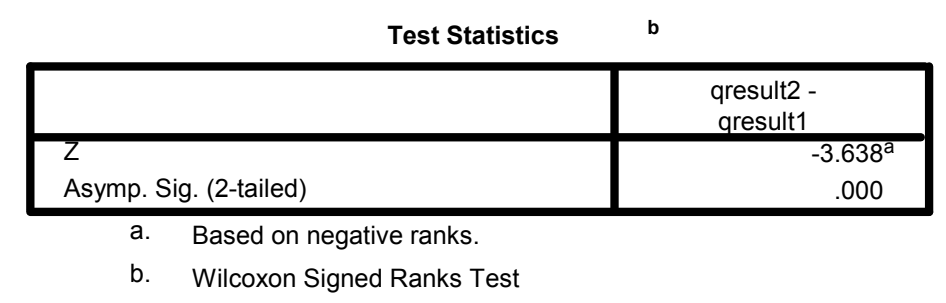


Table 4.2. indicates that the $\mathrm{p}$ value of .00 is much lower than .05 . This indicates that there exists a statistically significant difference between the ranks. As a result, the first null hypothesis stating that the application of podcasts as a motivational teaching strategy does not significantly affect the students' motivation for listening is rejected. In other words, the application of podcasts affected the participants' motivation for listening.

\subsubsection{Testing the Second Null Hypothesis}

The second null hypothesis of the study posed that the motivated students do not outperform significantly the less motivated learners on the test of listening comprehension. In order to test the hypothesis, an independent samples t-test was used (SPSS 13) to examine if the experimental group performed better than the control group in the administration of the listening post-test. Table 4.3 below shows the results of the independent-samples t-test.

\begin{tabular}{|ll|r|r|r|c|}
\hline & Group Statistics \\
\hline & group2 & $\mathrm{N}$ & Mean & Std. Deviation & $\begin{array}{c}\text { Std. Error } \\
\text { Mean }\end{array}$ \\
\hline postscormain & 1.00 & 17 & 14.7647 & 1.25147 & .30353 \\
& 2.00 & 16 & 13.6250 & 1.36015 & .34004 \\
\hline
\end{tabular}

As shown in Table 4.3., the mean scores of the experimental and control groups are 14.76 and 13.62, respectively. To examine whether there exists a statistically significant difference in the performance of the participants, Table 4.4 should be examined.

Table 4.4. T-value for the Listening Performance of the Groups in the Posttest

Independent Samples Test

\begin{tabular}{|c|c|c|c|c|c|c|c|c|c|c|}
\hline & & \multicolumn{2}{|c|}{$\begin{array}{c}\text { Levene's Test for } \\
\text { Equality of Variances }\end{array}$} & \multicolumn{7}{|c|}{ t-test for Equality of Means } \\
\hline & & \multirow[b]{2}{*}{$\mathrm{F}$} & \multirow[b]{2}{*}{ Sig. } & \multirow[b]{2}{*}{$t$} & \multirow[b]{2}{*}{ df } & \multirow[b]{2}{*}{ Sig. (2-tailed) } & \multirow{2}{*}{$\begin{array}{c}\text { Mean } \\
\text { Difference }\end{array}$} & \multirow{2}{*}{$\begin{array}{l}\text { Std. Error } \\
\text { Difference }\end{array}$} & \multicolumn{2}{|c|}{$\begin{array}{l}95 \% \text { Confidence } \\
\text { Interval of the } \\
\text { Difference }\end{array}$} \\
\hline & & & & & & & & & Lower & Upper \\
\hline postscormain & $\begin{array}{l}\text { Equal variances } \\
\text { assumed }\end{array}$ & .056 & .815 & 2.507 & 31 & .018 & 1.13971 & .45462 & .21251 & 2.06690 \\
\hline & $\begin{array}{l}\text { Equal variances } \\
\text { not assumed }\end{array}$ & & & 2.500 & 30.358 & .018 & 1.13971 & .45580 & .20930 & 2.07011 \\
\hline
\end{tabular}

As you can see in Table 4.4, the p value of .018 is much lower than .05 . This indicates that there is a statistically significant difference between the means. Therefore, the second null hypothesis is not confirmed, either. The second null hypothesis had stated that motivated students do not significantly outperform the less motivated students on the test of listening comprehension. In other words, the participants' achievement in terms of listening ability was affected by the incorporation of podcasts. The application of the treatment improved the participants listening comprehension ability.

\subsubsection{Qualitative Data Analysis}

A bio-data questionnaire given at the beginning of the semester to elicit information about students' past learning experiences showed that none of the students had the experience of practicing listening using podcasts. They all practiced listening using traditional methods in their previous classes. In this section, two issues will be discussed. First, the results of researcher-made podcasting questionnaire which was given to elicit students' perceptions about podcasting project will be analyzed. Then, the transcripts of the interviews with students will be closely investigated to find out students' view points about the podcasting project.

\subsubsection{Learners' Perceptions about the Effect of Podcast Program on their Listening Comprehension Ability}

To triangulate the findings in the quantitative section, the participants' perceptions about listening to podcasts were elicited via a researcher-made questionnaire. The researcher used Likert scales to elicit the participants' responses. The students were also allowed to respond with free text comments. The data were entered into Excel for analysis and reporting. Free comments were studied and themes were extracted.

The participants in the experimental group were 17 male students. When the podcast program was over, they were given the questionnaire and asked to select the choices based on their own perceptions. They were reminded that there are no wrong answers. After each item, some spaces were provided for any students' comments. They were not asked to write their names on the questionnaire so that they would be assured of the confidentiality of the information they provided.

\section{Item 1: I often feel bored when listening to podcasts.}

Most of the responses to this item were negative. Sixty-five percent of the participants $(n=11)$ strongly disagreed or disagreed that the podcast experience was boring for them. About twenty-nine percent of the participants $(\mathrm{n}=5) \mathrm{had}$ neutral ideas about the experience and about six percent of them $(n=1)$ agreed with the statement. Three students 
commented that, at first, listening to podcasts seemed to be tiresome but gradually they enjoyed listening to them, especially when they discovered new spoken idioms and expressions in the content of podcasts. As one of them commented, "I sometimes came up with expressions I was long looking for, it was just what I wanted in these years". Another student commented, "Podcasts are interesting, because it discusses the most important subjects and give information about cultures". A student, however, commented that he felt bored because he could not focus on the content.

\section{Item 2: I like to learn English listening comprehension mainly through podcasts because listening is very important.}

The second item is related to the importance of listening and listening to podcasts. More than half of the students (59\%; $\mathrm{n}=10)$ stated that they would be willing to use podcasts to practice listening skill. Only 3 participants $(18 \%)$ were not sure about their willingness to utilize podcasts as listening materials and four of them (24\%) disagreed with their likelihood to use podcasts again in future. There were two learner comments with regard to this question. One learner said that "Listening is an important ability, but podcasting is only one way, I have other things for improve my listening." The other participant said: "My listening isn't good. I like to be better, so I will listen to everything which helps me. And listening is so cool."

Item 3: I feel that I can learn through podcasts.

The third item is related to the usefulness of podcasts as learning tools. The majority of the respondents $(\mathrm{n}=15 ; 88 \%)$ perceived that they consider podcasts as learning tools. One participant $(6 \%)$ was not sure about the item in question and only one of the responses $(6 \%)$ was negative. There was only one student comment on this question. The student said that: "Speakers of this podcast file were so great. They were like classroom teachers. I sometimes feel I am in classroom teaching me. I could not just ask them questions."

Item 4: I would like teachers to use podcasts in my classes.

This item addressed the question whether participants of the study as Iranian EFL learners would like their teachers to use podcasts as listening materials and lerning tools in their classroom. The greater part of the respondents $(\mathrm{n}=11 ; 65 \%)$ agreed with the idea. However, two of the participants (12\%) disagreed with the idea and four participants (23\%) were not sure about the statement. One student commented: "Podcasts are so funny and they teach me interesting and useful things. I thank you my teacher to use it in the classroom." Two other students believed that podcasts are new and different from what they had already learned in previous classes.

Item 5: I like listening to podcasts.

Most of the responses to this item were affirmative. Seventy percent of the participants $(n=12)$ strongly agreed or agreed that they liked to listen to podcasts. About eighteen percent of the participants $(n=3)$ had neutral ideas about whether they liked listening to podcasts and about twelve percent of them $(\mathrm{n}=2)$ did not like listening to podcasts. To this item, three students put their written comments. Two of them unanimously agreed with the idea that podcasts had motivated them to listen more. However, one student did not like the idea of listening to podcasts. He stated: "They are so boring, so I don't like listening to them. They are so easy, too. Honestly speaking, it was waste of time for me."

Item 6: In order to improve my English listening comprehension, I will spend much of my studying time listening to podcasts.

The response to this item is, somewhat, different from the response given to the previous items, inasmuch as about half of the participants perceived that the listening to podcasts was not their first priority in learning English. Three of the participants (18\%) were not sure about this idea; however, six of them stated that they would spend their time listening to podcasts. Some students noted that there are other aspects of language which they need to spend more time on. As one student said, he has little problem with listening, therefore, he needs to spend most of his time practicing speaking. One student commented that the course was useful in introducing him the podcasts, and from then he would listen more to podcasts to practice listening.

Item 7: I often feel nervous and uncomfortable when listening to podcasts.

Nearly most of the responses to this item were negative. Fifty-nine percent of the participants $(n=10)$ strongly disagreed or disagreed that listening to podcast did not create any uneasiness or nervousness for them at all. About twenty-three percent of the participants $(n=4)$ had neutral ideas about the experience and about eighteen percent of them $(n=3)$ agreed that they didn't have good time listening to podcasts. Six students commented on this statement. While, one of them wrote: "I started well first, but after just two minutes I can't focus on content. It's so hard to understand everything.", and as another learner's comment was affirmative as well, others believed they had no or few problems when listening to podcasts.

Item 8: I am sometimes unable to focus on and understand the content of the materials when listening to podcasts.

Responses to this item were also variegated. Not all of the students could often understand and focus to the content of podcasts. While five of the participants $(29 \%)$ had no idea about the statement, seven participants stated that they had problems listening to podcasts, and five participants $(30 \%)$ disagreed with the statement. There were six rather short comments on this statement. All of them answered they sometimes had problems understanding the content of the materials. 


\subsubsection{Learners' points of views on the podcast program}

To examine the appropriateness of podcasts project for Iranian EFL learners, the study took participants' views towards the process into consideration. To do this, interviews were carried out with students of different listening abilities (four learners with highest listening scores and four learners with the lowest listening scores) with the anticipation of seeking different opinions.

The interviews were transcribed and were, then, analyzed inductively and the themes emerging from the transcriptions were identified. The main themes were listening achievement, learning by listening, learner choice and flexibility, and podcasts as a useful supplementary tool as explained below.

Listening achievement: In their interviews, the participants stated their ideas about their progress in listening ability. The students unanimously perceived improvement in their listening comprehension ability. They believed they were able to learn a lot of new vocabulary and they have now sharper ears for spoken language. As one said:

"I am sure from now on I would have no problem listening to different listening materials if they are not much above my level."

Some of them reiterated that they have now more confident listening to different stories or lectures. One student said:

"The podcasts program helped me to willingly listen more by giving me more confidence and motivation in comprehending and by forcing me to do a lot of listening"

Although almost every learner perceived that the podcasts experience helped them improve their listening comprehension, they believed that they still needed more practice and there was still room for development.

Learning by listening: Some of the interviewees believed that the process of learning by listening is easier than reading printed words. In this regard, one of them said:

"To sit down and to read is very challenging; you have to be stuck in one place for a long time. But audio is not like that. It is easier to learn when we listen, especially when you understand everything",

Another participant said:

"I think it is the best practice for our pronunciation. We can listen to words and we can check the pronunciation of words against mine, in this way, I can check or learn a lot of words' pronunciations because everything is so fast and I don't need to check them in my dictionary"

As previously mentioned in 3.1 none of participants had experienced podcasts as a learning tool. As a result, they agreed that podcasting was such a new phenomenon for them. One of the students affirmed that learning with podcasts represented an attractive learning experience:

"That is a very new experience. In fact I've never heard of podcasts before this class, I didn't know what podcasting was."

Podcast as a useful supplementary tool: The final theme is the learners' awareness of supplementary nature of podcasts as a learning tool for outside of the classroom learning. As one of them said, "podcasting provides me an additional exposure to learn English. I think I need to practice more and more listening". Another student also said that "There is a lot to listening and I should do a lot of listening to become better in listening comprehension. With using podcasts I can practice listening at home."

The learners also pronounced the fact that listening skill is their Achilles' heel, and they needed to have a lot of practice both inside and outside of the classroom. As one of them said, "I'd like you (the teacher) to introduce me more sources of podcast files so that I can use them in my free time". Still another learner said that listening to podcasts helped him to understand that he does not need to constrain his listening practice to classroom time.

Having experienced podcast project, the learners were aware of the advantages and disadvantages of the podcasting program. As for the advantages of the program, one of the students commented that podcasts made him somehow independent in terms of listening and vocabulary learning. Some of them found podcast experience useful for some aspects speaking skill as they could pause after each sentence and repeat after the model. Students overwhelmingly preferred using new technology to traditional methods of listening. They said that by this type of learning they can feel the presence of new age of technology: "I am tired of using my cell phone for just messaging and listening to music. Now, I have another application for it. I am happy to use it for my English learning".

The students also noted the disadvantages of the program. Almost half of the interviewees said that some podcasts were so lengthy and not enough interesting so that it was sometimes difficult to focus on the content. It should be mentioned that one participant regarded having students listen to podcasts more than once as useless activity. As the transcript reads: "they [podcasts] were so easy, so it was very boring job to listen to them more than once. I think they are useless when they are very easy". Another disadvantage they mentioned was the shortage of lack of pictures and videos accompanying audio. One learner, intellectually, noticed that podcasts suffer from the fact they are one-way learning objects "we cannot interact with files, we must just listen them to them, and when we have questions, we cannot ask them. But, when we listened to them in class, that was no problem."

\subsubsection{Discussion of the Qualitative Data Analysis}

To investigate students' perceptions about podcast program, the participants were given a questionnaire. An overwhelming majority of the participants perceived the whole program as positive. Also, the majority of them deiced 
to continue to do podcasting in the future. Based on this survey, the majority of the respondents $(88 \%)$ perceived that they consider podcasts as useful learning tools. Furthermore, exactly seventy percent of the participants liked the experience.

To enrich the findings, students' perceptions about their novel listening experience were also tapped on using semistructured interviews with learners of different listening ability. The interviews were transcribed and analyzed to identify the themes. The major extracted themes from the data were listening achievement, learning by listening, learner choice and flexibility, and podcasts as a useful supplementary tool.

The participants had a positive attitude toward podcasting and believed that podcasting helped them to grow an interest in listening.

\section{Discussion and Implications}

The last section of the study focuses on the restatement of the problem and summary of the major findings. The results of statistical analyses are discussed with reference to the relevant literature. Later, educational implications are discussed. Finally, the concluding remarks about the findings are presented.

\subsection{Discussion}

Quantitative data analysis revealed that podcasts had an effect on improving learners' motivation for listening. As mentioned by Brett (1995), podcasts as multimedia-based language learning tools create learning motivation. According to Brett, "this may be due to the way in which individuals can tailor their learning or may be a case of novelty, a matter for further investigation" (op. cit.: 84). Experimental group's improvement in levels of motivation might also be due to their awareness of the fact that it is possible to perform better in terms of listening comprehension due to using the new technology. Learners in the experimental group gained higher scores on the post-administration of the listening test. Although this might be due to test effect, it should be mentioned that they outperformed the participants on the post-test scores. The results, also, reflect findings achieved earlier in the related literature. They are in line with Rost's (2006), Madrid's (2002), Cebeci \& Tekdal's (2006), and O'Bryan and Hegelheimer's (2007) findings that podcasts can be used in the educational settings in general and language teaching in particular to motivate students. Moreover, the point that podcasts can make learners more motivated for listening and learning is frequently mentioned in the literature (e.g. Barrett et al; Borja, 2005; Cambell, 2005; Evans, 2008; Maag, 2006; Newton, 2005; 2006; Van Ittersum \& Johnson 2006). The results of this study also contradict earlier findings in the literature. For example, contrary to Atkinson's (2006) and Cann's (2007) findings, the participants of this study endorsed the use of podcasts in their classes as they stated that podcasts were useful learning tools for them and they could learn through listening to podcasts.

As for the second null hypothesis, to check whether the experimental group outpaced the control group in the postadministration of the listening test, the parametric test of independent samples t-test was applied. The results showed that listening to podcasts improved the learners' listening scores in the experimental group. Although, the benefits of podcasting on language education have been marked by some writers, particularly in terms of empowering learners' with listening and speaking skills (e.g. Pun, 2006; Stanley, 2006), there is no study in the literature, investigating influence that listening to podcasts can have on listening scores of learners. This study provided evidence that listening to podcasts might be helpful for EFL learners to improve their listening ability.

Podcasts could be used in language classes, on the one hand, to help teachers and learners with auditory skills (Stanley, 2005), and on the other hand, to enhance learners' motivation in learning, especially listening (e.g. Hasan \& Hoon, 2012; Newton, 2005; 2006; Van Ittersum \& Johnson, 2006). In brief, this research paper displayed podcasts potentials in promoting Iranian EFL learners' English listening ability. The results demonstrated the effectiveness of podcasts as supplementary teaching tools on the learners' overall listening ability and their motivation for listening. The learners also welcomed podcasts as a learning tool. The learners' positive perceptions might be due to the convenience of using podcasts (Gibson, 2006; Shandle \& Swanigan, 2005), or because they were motivated to listen more to listening materials (Barrett et al; Borja, 2005; Cambell, 2005; Evans, 2008; Maag, 2006; Newton, 2005; 2006).

Podcasts can be employed in EFL classes as a teaching and learning tool to motivate learners by including interesting items (Fothergill, 2007), and by "encouraging active learning" (Jenkins and Lynch, 2006; Lum, 2006).

\subsection{Implications of the Study}

This study has some implications for teaching and curriculum development in the Iranian EFL context. First, podcasts as a new technology accepted worldwide should be given their due attention in teaching of language auditory skills specifically listening. EFL teachers are recommended to introduce and implement podcasts in their classes. This might influence student learning experience in a positive way. Learners might be more responsible for and autonomous in improving their listening ability. Podcasts can be used by EFL teachers both directly in the classroom and out of the classroom as a supplementary tool. It can also be practiced out of the classroom while doing some related tasks in the classroom monitored by teacher, chiefly to save time.

In developing curricula and writing syllabi, it's better to pay special attention to students' likeliness to take advantage of new technology. With the growing interest in using internet among young learners, teachers and curriculum developers should try to bring technology to the classrooms. This not only will give the teachers a useful asset in following their teaching objectives but also will be a motivating factor for students to pursue their learning more meaningfully. 
However, it should be mentioned that the implementation of podcasts in EFL classes needs careful planning and adequate training of teachers so that it becomes an effective teaching and learning tool.

\section{References}

Adams, C. (2006). Geek's guide to teaching in the modern age. Instructor, 115(7), 48-51.

Alison, J., \& Halliwell, S. (2002). Challenging Classes: Focus on Pupil Behaviour. London: CILT.

Ashraf, H., Noroozi, S., \& Salami, M. (2011). E-listening: The promotion of EFL listening skill via educational podcasts. Retrieved from http://ehis.ebscohost.com/ehost/

Brown, H.D. (2001). Teaching by Principles (2nd edi.). New York: Longman.

Cebeci, Z., \& Tekdal, M. (2006). Using Podcasts as Audio Learning Objects. Interdisciplinary Journal of

Knowledge and Learning Objects, 2, 47-57.

Chambers, G.N. (1999). Motivating Language Learners. Clevedon: Multilingual Matters.

Chang, S. M. (2001). Students' reasons and motivation for learning English. Proceedings of the eighteenth conference on teaching English and learning in R. O. C. Taipei, Taiwan: Crane.

Cheng, H. F., \& Dornyei, Z. (2007). The Use of motivational strategies in language instruction: The case of EFL

Teaching in Taiwan. Innovation in Language Learning and Teaching, 1(1), 153-174.

Covington, M.V. (1998). The Will to Learn: A Guide for Motivating Young People .Cambridge: Cambridge University Press.

Crookes, G., \& Schmidt, R.W. (1991). Motivation: Reopening the research agenda. Language Learning, 41, 469-512.

Dornyei, Z. (1990). Conceptualizing motivation in foreign-language learning. Language Learning, 40, 45-78.

Dornyei, Z. (1994). Motivation and motivating in the foreign language classroom. Modern Language Journal, 78, 273284.

Dornyei, Z. (2001b). Motivational Strategies in the Language Classroom. Cambridge University Press.

Dornyei, Z. and Csize'r, K. (1998) Ten commandments for motivating language learners: results of an empirical study. Language Teaching Research, 2 (3), 203-229.

Dunkel, P. (1986). Developing listening fluency in L2: Theoretical principles and pedagogical considerations. The Modern Language Journal, 70, 99-106.

Ehrman, M., Leaver, B., \& Oxford, R. (2003). A brief overview of individual differences in second language learning. System, 31, 313-330.

Gardner, R.C., \& Lambert, W.E. (1959). Motivational variables in second language acquisition. Canadian Journal of Psychology, 13, 266_272.

Gardner, R.C., \& Lambert, W.E. (1972). Attitudes and Motivation in Second Language Learning. Rowley, MA: Newbury House.

Guilloteaux, M.J., \& Dornyei, Z. (2008). Motivating Language Learners: A Classroom-oriented Investigation of the Effects of Motivational Strategies on Student Motivation. TESOL Quarterly, 42 (1) 55-77.

Hasan, Md. M., \& Hoon, T. B. (2012). ESL Learners" perception and attitudes towards the use of podcast in developing listening skills. The English Teacher, 41(2), 160-173.

Madrid, D. (2002). The Power of the FL Teacher's Motivational Strategies. Cauce, 25, 369-422.

Oxford, R.L., \& Shearin, J. (1994). Language learning motivation: Expanding the theoretical framework. Modern Language Journal, 78, 12-28.

O-Bryan, A., \& Hegelheimer, V. (2007). Integrating CALL into the Classroom: the Role of Podcasting in an ESL Listening Strategies Course. ReCALL, Vol. 19(2), 162-180.

Pun, S. W. (2006). The educational applications of podcasts [In Chinese]. In Hong Kong Association for Computer Education 2006 Year Book (pp. 23-28). Retrieved January 17, 2007, from http://www.hkace.org.hk/ publication/yearbook/YearBook05/25-5-06Year\%20Book1-56.pdf

Rost, M. (2006). Listening in action: Activities for developing listening in language teaching. Englewood Cliffs, NJ: Prentice Hall.

Selingo, J. (2006). Students and teachers, from K to 12, hit the podcasts. New York Times, p. G4.

Stanley, G. (2005). Podcasting for ELT. Retrieved January 17, 2007, from http://www.teachingenglish.org.uk/think/resources/podcast.shtml

Stanley, G. (2006). Podcasting: Audio on the Internet comes of age. TESL-EJ, 9(4). Retrieved January 17, 2007, from http://www-writing.berkeley.edu/ TESL-EJ/ej36/int.html

Tremblay, P.F., \& Gardner, R.C. (1995). Expanding the motivation construct in language learning. Modern Language Journal, 79, 505-520.

Wikipedia (2005). Podcast definition (last modified 02:21, 13 Apr 2005). Retrieved January 2, 2011, from http://en.wikipedia.org/wiki/Podcast.

Williams, M., \& Burden, R. (1997). Psychology for Language Teachers. Cambridge, England: Cambridge University Press. 